\title{
Discussion of the foreign "double type" teachers' team construction in vocational colleges
}

\author{
Yao Wei \\ Dalian Vocational Technology College, Zip code: 116035, China
}

\author{
Key words: Foreign vocational college; Double type; Teachers; Experience; Revelation
}

\begin{abstract}
Double type" teaching staff is the important guarantee of talents training in higher vocational education system, especially in a lot of foreign education systems, there are a lot of "double type" teachers construction of successful cases. These higher vocational colleges have a strict standard, perfect training system, perfect selecting system,etc., such as the development of higher vocational education in China has guidance and reference. In this paper, by analyzing the foreign vocational college "double type" teachers team construction experience, explore overseas higher vocational "double type" teachers team construction on our country's enlightenment, aims to provide reference for the improvement of the higher vocational education system in our country.
\end{abstract}

\section{Introduction}

The most direct purpose of education and teaching in higher vocational colleges is to cultivate the talents needed by society, so in the process of teaching should pay attention to the combination of theory and practice, this is the important way of cultivating students' professional ability and professional skills. The root of the higher vocational education teaching is built on a solid theoretical knowledge, and to achieve the practical teaching and professional knowledge of the organic integration. In the process, need to have higher professional ability and professional quality of teachers' guide, determines the higher vocational teachers must have the "double type" quality know both theory and practice. But because of higher vocational education in China starts late, in the aspect of "double type" teachers team construction also has a large lag, therefore, we should actively learn from the successful experience of the construction of foreign higher vocational teachers and improve the quality of higher vocational education in our country.

\section{Foreign vocational college "double type" teachers team construction experience}

\subsection{National "double type" teacher qualification requirements}

Japan for higher vocational colleges of "double type" teachers decided: must have a master's degree, and it must be related to its teaching content of academic research results, as well as the corresponding operational capacity. Countries such as Australia and Denmark requires teachers need to have more than 5 years of professional work experience. German vocational education teachers must obtain a doctorate degree and have at least 5 years of professional experience in the business, etc. ${ }^{[1]}$. Each country of "double type" teachers' qualifications have different standards, but the common is that the general admission requirements are higher, especially the teacher's work experience and practice ability become the consensus of most countries.

\subsection{Higher vocational college "double type" of teachers training mode}

Denmark's "double type" teachers' training is on the basis of experience in professional skills, supplementary education teaching professional knowledge skills training. German "double type" teachers' training is to through professional qualification training and education theory study, need teachers have professional skills and training equipment of the skilled operation ability. In Japan, "double type" teachers' training is mainly based on professional disciplines as the core, after the teacher is qualified as a professional teacher, need to practice training in specific enterprises, have a certain practical ability to transfer to a teacher post. 


\subsection{Foreign management mode of "double type" teachers}

Many foreign countries such as Japan, America, Canada and other countries have strict management system, and the number of part-time teachers is much higher than full-time teachers, the system of employment is a tenure system, this is also the foreign vocational "double type" teachers in the building of the common ground, and there is big difference between the Chinese business establishment. Foreign teachers in vocational colleges is mainly based on short-term contracts, is basically a sign every year, according to education funds and the basic situation of teachers' work decided to the teacher's future ${ }^{[2]}$.

\subsection{Foreign "double type" team incentive mechanism}

From the survey results show that foreign vocational education in the "double teacher" teachers pay and social welfare should generally be higher than the ordinary school teachers. So many foreign vocational colleges "double type" teachers are relatively stable. Especially in Germany, "double type" teachers' status and salary are very high, this kind of incentive mechanism has a strong appeal, to improve the cohesion of the teacher plays a positive role.

\section{The Influence of Foreign vocational college "double type" teachers team Construction on our country}

\subsection{Clear higher vocational college "double type" teachers' qualifications}

Higher vocational colleges in our country "double type" teachers' qualifications are relatively low, access rules are not very strict. For example, many vocational school teachers in our country entry requirements is to obtain related colleges and universities teachers' qualification certificate, education requirements undergraduate. Although the requirements for "double teacher" teachers are relatively high, but the lack of operability in the limited standards. For example, the main sources of higher vocational teachers in China are college graduates, enterprise employees, institutions retirees, etc., from the side also reflects the "double type" teachers as the standard in our country is not unified and strict ${ }^{[3]}$. "Double type" teachers is compound talents with professional knowledge and practical operating ability, so our country should learn the principle of access to foreign vocational institutions, prominent the skills, engineering and other professional features, improve the academic standard.

\subsection{To help higher vocational college "double type" teachers to update their knowledge structure}

Most of the vocational training of teachers in our country adopts the way of on-the-job training. The training way although time is short, won't take up much of teachers' teaching time, but this is a way of compensating education, to improve the teachers' professional practice ability did not play effective role, it is difficult to solve the problems in higher vocational colleges "double type" teachers' team construction in our country. So higher vocational colleges should combine their own actual situation in our country, learn from foreign vocational education and social enterprises a high degree of joint training model, to strengthen teachers' training, so that teachers not only have a professional theoretical knowledge, but also have a high professional practice ability. In the process of participating in the production process to absorb the latest technical information, used in teaching, constantly improve their teaching strength, to achieve from a single type of teaching to the "double type" teachers' change.

\subsection{Establish ZhuanJian combination of "double type" teachers in higher vocational colleges} The biggest difference between higher vocational colleges and institutions of higher learning is that higher vocational colleges not only have the attributes of higher education, but also have the attributes of vocational education. So higher vocational colleges in our country the construction of "double type" teachers should learn from foreign experience, to build a ZhuanJian combination of teachers, encourage higher vocational colleges to employ part-time teachers, this will not only save the cost of education, improve the effectiveness of running a school, but also timely absorption of new talent and new technology to improve the quality of personnel training. For example, higher 
vocational colleges to introduce part-time teachers from enterprises and institutions, brings the new technology of first line production and scientific research, can quickly adjust the teaching model according to social conditions and market requirements, maximum play to the social benefits of higher vocational education. Finally, part-time teachers have a shorter term of office, higher vocational colleges in our country can implement part-time teacher tenure system, to achieve teacher management from the "identity management" to "job management" change, merit appointments, to achieve the quality of education to enhance.

3.4Improve teachers' incentive mechanism, improve the treatment and status of the "double type" teachers

The lack of competitive atmosphere and consciousness in the educational environment of higher vocational colleges, to improve the level of teachers' education and teaching have a negative impact, only to let it in a sense of occupational crisis in order to stimulate its positive spirit. Research show that employees can only play $10 \%$ to $30 \%$ of their job potential in a lack of incentives, in the right competitive and stimulating environment, the employee's potential can be stimulated to $80 \%$ $-90 \%{ }^{[4]}$. So higher vocational colleges in our country should actively learn from foreign good "double type" teachers in higher vocational colleges treatment welfare mechanism, effectively raise teachers' wages and welfare, stimulate the enthusiasm of teachers work. In addition, the appropriate internal competition atmosphere established between teachers, let teachers constantly improve their professional knowledge and technical ability, remain competitive. Finally, to establish scientific evaluation system, at present higher vocational colleges in our country generally used ordinary university education evaluation mode, that is still the "one-way line" professional teacher evaluation model, it is not suitable for vocational colleges teaching evaluation. So higher vocational colleges in our country should actively learn from foreign advanced teacher evaluation mechanism, establish theory and business ability comprehensive evaluation mechanism, reform the traditional evaluation system, make "double type" team building standardization and professionalism.

\section{Conclusion}

To sum up, the foreign education system of "double type" teachers construction has a strict standard, perfect training system and perfect selection system,etc., The development of high school education in our country has guidance and reference. Higher vocational colleges in our country should clear higher vocational college "double type" teachers' qualifications. To help higher vocational college "double type" teachers to update their knowledge structure. Establish ZhuanJian combination of "double type" teachers in higher vocational colleges. Improve teachers' incentive mechanism and improve the treatment and status of the "double type" teachers. To achieve from a single type of teaching to the "double type" teachers' change. Improving the quality of education and teaching in higher vocational colleges.

\section{References}

[1] Yang Shasha. Foreign "double type" teacher training model comparison and enlightenment to China [J]. Adult Education, 2015 (06).

[2] Li Na, Zhang Junling. Foreign vocational education teacher training mode of "double type" teacher training in China enlightenment [J]. Journal of Jincheng vocational and technical college, $2016(02)$.

[3] Xue Xiaoyu. Foreign vocational education teacher training to build our "double type" teacher training system enlightenment [J]. New West (late), 2012 (10).

[4] Cheng Xiazhen. Foreign vocational school "double type" teacher team construction practice and its enlightenment to China [J]. Journal of Hubei Correspondence University, 2011 (08). 